\title{
Gender in Children's Literature: Through or Beyond Conventions?
}

\author{
Dimitrios Politis \\ Department of Educational Sciences and Early Childhood Education, University of Patras, Patras, Greece \\ Email: dimpolitis@upatras.gr
}

How to cite this paper: Politis, D. (2022) Gender in Children's Literature: Through or Beyond Conventions? Advances in Literary Study, 10, 129-140.

https://doi.org/10.4236/als.2022.102010

Received: January 5, 2022

Accepted: January 27, 2022

Published: January 30, 2022

Copyright (c) 2022 by author(s) and Scientific Research Publishing Inc. This work is licensed under the Creative Commons Attribution International License (CC BY 4.0).

http://creativecommons.org/licenses/by/4.0/

\begin{abstract}
Gender has always been considered as a basal issue in the field of Children's Literature. Since children are receptive to the values and impressed by the ideas expounded in what they read, literary texts addressed to children are not just simply for entertainment; they also reflect positively all of society, especially the marginalized. Children's Literature should inspire and enthuse its audience, while it could be a means of escape, a sanctuary from repression, and a "secret garden" within which children can identify with and rejoice in themselves. In order to illustrate how gender is used both negatively and detrimentally to the perception of the self, and then to examine whether the "sacrifice" of the story for socially correct writing is acceptable or desirable, we will examine in this paper indicatively, but representatively, the presentation of gender in various texts for children, from fairy tales and nursery rhymes to classic or modern novels and adolescents' fictions. Finally, as this brief study shows, though Children's Literature cannot on its own subvert ideology, gender definitions, or gender stereotypes, it could shape a new basis for thinking about individuality and humanity, by challenging children to question and to cogitate.
\end{abstract}

\section{Keywords}

Gender, Children's Literature, Self-Perception

\section{Introduction}

As an oppressive political tool, a social construction dictating a set of culturally defined characteristics which define what we will be, gender is the chief cause of the evils of stereotype and sexism. Its aim is to ensure the preservation of society by coercing the suppression of our essential natures and forcing us to embrace our culturally defined selves (Goodman, 1996: p. vii). However, it is much more 
than a matter of biology, "a person's sex", as it dictates the essence of sex, the characteristics and status of masculinity and femininity especially in the context of feminist theories (Paul, 2004). Gender illustrates the triumph of nurture over nature, while its influence is so entrenched and pervasive that it is perceived as being the natural order of things. By subordinating our natural selves, problems of identity arise, while issues of marginalization occur. People are repressed and stultified by their roles ever conscious that they do not fit the ideal, causing unease, unhappiness, displacement, the destruction of self (Copenhaver, 2002: pp. 16-18, 24-73; Butler, 2004, 2006; Ferrarelli, 2007).

Children's Literature is not just to entertain, it has a duty to reflect positively all of society, especially the marginalized, and it should inspire and enthuse its audience. Let it be escapist, a sanctuary from repression, a secret garden within which children can identify with and rejoice in themselves. If literature has the duty of deepening, enriching, or extending children's lives and experiences (Peterson \& Swartz, 2008: pp. 18, 20-21), it must be careful of the ideas it sanctions in literary texts, the very values it dictates, the gender models it proposes. By holding a mirror up to nature, literature should do just that and not merely reflect the politically desired ideals of identity (Peterson \& Swartz, 2008: pp. 139141). This is not helped, if the images projected by literary texts show no reflection of self or show a degraded parody of one's essential being.

Conventionally, gender confers a set of opposing attributes and characteristics which are our essence as men and women: men embrace the characteristics of strength, logic, aggression and leadership; women are modest, silent, nurturing, humble and subservient. Although these characteristics presented as exclusive to each group and they may not be in themselves bad, they could become destructive through the demand that we operate within their limited definition (McCallum \& Stephens, 2011: pp. 364-367). If we forget our lines, or fail to play our parts, we are termed unnatural, unmanly, we become deviant. If we are untrue to ourselves we are dishonest, it is a poor society that is built upon the oppression and negation of self. An environment founded upon and preserved through deceit is not a culture in which we can thrive (Flanagan, 2010: pp. 32-33).

Since "Children's Literature has primary significance in shaping gender identities" (Jabeen \& Mehmood, 2014: p. 240), by examining the presentation of gender in various works for children, from nursery rhymes and fairy tales to some representative modern novels intended for teenagers, we hope to illustrate throughout this specific paper how gender is used both negatively and detrimentally to the perception of the self and the individuality. In addition to the main aim this study, we would also to consider whether the exploitation, namely the "sacrifice", of poetic ideas or fictional devices for socially correct writing is acceptable or desirable.

\section{Emerging Genders, Happy Children?}

From the cradle, children are introduced to fairy lore, stories and nursery rhymes 
which whilst often fantastic and entertaining set the stage for and define the characteristics the child must embrace, the essence of their maleness, femaleness. An indicative but representative sample is given below:

"What are little boys made of?

What are little boys made of?

Snips, snails

And puppy-dogs' tails

That's what little boys are made of.

What are little girls made of?

What are little girls made of?

Sugar and spice

And everything nice [or "all things nice"]

That's what little girls are made of."

(Opie \& Opie, 1997: pp. 100-101).

Girls are nice, sweet things, whilst boys are conversely sinister, reptilian. In many classic fairy tales such as Snow White ${ }^{1}$ and Sleeping Beauty, ${ }^{2}$ children are shown images of women, ideals of femininity. In these tales both heroines are beautiful, both are put into danger through the jealousy of older women, the archetypal wicked stepmother and the witch. What is most striking about these tales is the silence of the heroines. Both are silenced by the actions of their older, jealous rivals. They are both shown as paragons of femininity in their silence; silence is equated with feminine virtue. Neither woman has any control over her destiny, but passively awaits the arrival of a male who will release her from her sleep. Their identity is conferred upon them by the Princes who break the spell by kissing them. It is worth noting that both women are powerless over their destinies and that it is the male characters who give them definition and life, make them whole (Temple, 1993; Ernst, 1995: pp. 66-78; Nebbia, 2016). Both these tales belong to those classic stories who "work", they "stick" at the heart of our culture, according to Jack Zipes (2006), as they have wide social and cultural ramifications that help us theorize and challenge our lives and our values.

The ubiquitous witch of fairy lore is an enigma produced through gender confusion. Whilst the essence of femininity is characterized by nurturing, modesty and silence, it is also equated with chaos, disorder, emotion, fickleness, the moon. Women represent what is not understood, what is illogical, the darker side of creativity. These qualities of disorder are embodied in the witch who represents a threat to society in that she is beyond control, beyond comprehension. Gender, through conferring positive qualities of character on to men leave women to be defined by the opposing negative characteristics. Women, like the moon are shown to be changeable, the virgin and the witch are both possible manifestations of their femininity (Trites, 1997; Wilkie-Stibbs, 2002).

${ }^{1}$ We refer to the well-known $19^{\text {th }}$-century German fairy tale included in Grimms' Fairy Tales published by Brothers Grimm in 1812.

${ }^{2}$ It's about the classic fairy tale first published by Charles Perrault in Histoires ou contes du temps passé in 1697, and later by Brothers Grimm. 
The frailty of women is well documented within the Christian tradition. It is in Genesis [3:1-3:24] (Hamilton, 1990: pp. 186-218), ${ }^{3}$ the first book of the Hebrew Bible and the Christian Old Testament, that we are told how Eve succumbs to the temptations of the serpent, enticing Adam to partake of the forbidden fruit, resulting in their exclusion from paradise. We are told how a woman instigated the fall, the original sin. It is no wonder that women frequently feel stultified by their particular gender definition, a definition which confers such absolute responsibility and guilt (Fry, 2005: p.161).

In a Hans Christian Andersen's fairy tale entitled “The Tinderbox" (Andersen, 1976), ${ }^{4}$ we have all the ingredients of a classic tale: a witch, a soldier, treasure, fantastic dogs and a princess. The soldier is described as being a real man. A man of action, carrying a sword and returning from war. He is the vehicle of the action in the tale, The witch, described as "a disgusting sight, with a lower lip that hung all the way down to her chest" (p. 11), knows about the treasures held within the hollow tree, she is however unable to access them. Her knowledge is useless to her as she is incapable of action but seeks to achieve her goal through the soldier. The tale is unpleasant enough. The soldier dishonors his bargain with the witch, decapitating her for refusing to reveal what she wants the tinderbox for. He is now a rich man, setting himself up as a person of means. The towns-people impressed with the personage of this fine gentleman entice him to stay with reports of the King's daughter, "what a lovely princess his daughter was" (p. 14). The princess is notably silent throughout this tale. Her worth is defined by her beauty, she is a silent object, her fate dictated by both her father and the soldier. She herself has no control over her destiny and is defined by the men around her: both as an asset of the Kingdom and as a wife. What is interesting in this tale is the definition of real men and women. "She was so lovely that everyone would have known that she was a real princess. The soldier could not help kissing her, for he was a true soldier" (p. 15). The implication being that had the soldier not desired to kiss the princess he would not have been a real man. Heterosexuality, a desire to covet a person of the opposite sex is a foundation of gender. Whilst beautiful women embody true femininity.

In "The Princess and the Pea" (Andersen, 1976) femininity is equated with extreme sensitivity. The princess is shown to be real only through her inability to sleep due to the presence of a pea under an inordinate number of mattresses. The princess in "The Swineherd" (p. 32) is shown to be incapable of recognizing true worth. She exemplifies vanity and artificiality preferring toys to the natural beauty of the rose and nightingale. The princess prostitutes herself, kissing the swineherd in order to covet the music pot. Her inability to realize true values results in her being abandoned by her father and being rejected by the swineherd prince. The tale of "The Ugly Duckling" is a useful illustration of the problems

${ }^{3}$ See also: The Book of Genesis.

https://www.vatican.va/archive/bible/genesis/documents/bible genesis_en.html.

${ }^{4}$ The tale was one of the first nine fairy tales written by Andersen and included in the collection Fairy Tales Told for Children. First Collection. First Booklet between May 1835 and April 1837. 
that arise when you don't fit in, when you contradict your definition. The politics of the hen yard can be seen as a microcosm of society. The ugly duckling is rejected by his family and the society of the hen yard. There is no room for this outsider whose strangeness ostracizes him, as a freak he has no utility, he cannot be humored. "He's big and he doesn't look like anybody else", replied the duck who had bitten him "and that's reason enough to beat him" (p. 40). The tale has a happy ending; the ugly duckling metamorphoses into a swan, a noble beautiful bird. This, however, is the privilege of fantasy, while the politics of the playground are intractable. If children fail to adopt the dictated characteristics of their gender, they become marginalized, figures of fun. A crise of identity can result if children are unable to find a positive reflection of themselves. This is very destructive, marginalization as a misfit is not excusable as a character building exercise (Flanagan, 2010: p. 37).

\section{Transcending or Perpetuating Prejudices and Marginalizations?}

Writers of children's fiction have a moral responsibility to their audience. They must be accountable for the effect their writing has upon children. Thoughtless writing which encourages prejudice through the espousal of intractable, unrealistic ideals of gender is inexcusable (Flanagan, 2010: p. 37). There is presently a real dilemma of definition within Children's Literature. Should literature be a work of imagination, a fantastical escape from reality or an instrument of education? Some socially correct writing, whilst being inoffensive with regard to gender issues is bland, staid and uninspiring. It fails to enthuse or to encourage reading. The problem is one of striking a balance between writing that doesn't engender prejudice and marginalization but is still exciting and readable (Ernst, 1995).

If children are introduced to writings which are solely a mirror of the real world, what will happen to their imagination? Fantasy and mystery are essential forms of escapism, without which we risk creating myopic, "inverted" children. The ramifications of too much reality are seriously limiting if children are to see beyond the thing itself. A life without uncertainty, devoid of the crock of gold beyond the rainbow lacks possibility, lacks horizons. It is important that children are encouraged to think beyond the parameters of their own existence (Zipes, 2006; Peterson \& Swartz, 2008).

In My Dad Takes Care of Me by Patricia Quinlan (1987) we have a piece of writing which challenges stereotypical gender roles. The father is the career and nurturer, traditional roles are inverted, but at a cost. Since a factory closed and the dad lost his job, the family has to move to a new house, while dad becomes "home dad" taking care of a child. The writing, whilst unquestionably educational in terms of economics, market forces and gender roles, is both stark and uninspiring. This might be reality but who wants it? It is most striking for being utterly depressing, it smacks too much of education. The sacrifice is the charm 
of subtlety, the merits of good story telling.

The costs of harnessing imagination through pursuing a philosophy of education are well exemplified in Charles Dickens' (1854/1987) Hard Times. The novel is memorable for the starkness of the lives of the children, for the absence of beauty and the depressing certainty and monotony of the future.

"'You are not, Cecilia Jupe, [... ].You are to be in all things regulated and governed,' said the gentleman, 'by fact'” (p. 52).

"Now, what I want is facts. Teach these boys and girls nothing but facts.

Plant nothing else and root out everything else. You can only form the minds of reasoning animals upon facts: nothing else will ever be of service to them. This is the principle on which I bring up my own children, and that is the principle on which I bring up these children. Stick to facts, sir!” (p. 47). ${ }^{5}$

In Asha's Mums (Elwin \& Paulse, 1990) ${ }^{6}$ the gender roles embodied in the traditional family unit are challenged, Diane has two "mothers", the women are not defined in relation to their marital status but are ambivalently entitled "Ms".

"You can't have two mothers living together. My dad says it's bad", Corren insisted, "It's not bad. My mummies said we're a family because we live together and love one another", I said."But how come you have two?", Judi asked.

Before I could answer, Terrence said to Ms. Samuels, "Is it wrong to have two mummies?"

"Well", Ms. Samuels began, but Diane yelled "It's not wrong if they're nice to you and you like them" (Elwin \& Paulse, 1990).

Whilst this writing may be well intentioned exposing the marginalized invisible groups within society, its education aim is too overt. We do sanction the exposure of prejudice in writing, but not so blatantly. Actually, we should strive to combat the destructive limitations imposed by gender definition, but must avoid sacrificing the story and reading Children's Literature like an improving moral tract. Even today there is a sense that we have come to an impasse. Although we feel very strongly that gender as a social construct is through its rigidity of definition destructive to the identity of self, we are unable to advocate well intentional writing that sacrifices creativity for political correctness. This seems to be a substitution of evils (Butler, 2004; Butler, 2006).

Education is a very powerful tool and Children's Literature plays an integral role in the education of children. If literature is censored to ensure that children

\footnotetext{
${ }^{5}$ However, if we sacrifice fantasy in a strive for political correctness, we risk nurturing automatons, devoid of vision and individuality. For example, during the final voyage of the protagonist in Jonathan Swift's (1726/2005) Gulliver's Travels, the classic book of English literature, a fictional race of horses called "Houyhnhnms" represent pure unadulterated reason, as they lack imagination and life. ${ }^{6}$ Asha's Mums was one of the many banned titles in 1997. In 2002, the Supreme Court of Canada declared that such a discrimination couldn't be legally supported. (For more information see: https://www.freedomtoread.ca/challenged-works/ashas-mums/ \& https://en.wikipedia.org/wiki/Asha\%27s Mums).
} 
are not introduced to negative ideas of gender, we may produce a society of more integrated adults with secure ideas of self. The price would be to risk sacrificing freedom of expression, denying individuals the right to make informed decision of their own as to what is good or bad (Nebbia, 2016).

Categorizing men and women into gender definitions is a result of our desire to be in control. It is essentially human to try and make sense of our existence. We are lulled through labelling, defining and categorizing into a sense of being in control, that we understand what is going on. Our desire to define and regulate is well illustrated through the imposition of stereotyping, we strive to organize our reality through defining the categories and essence of masculinity and femininity (Nebbia, 2016).

Writers of children's fiction are similarly empowered. As Cheris Kramarae (1981: p. 165) suggests, "Those who have the power to name the world are in a position to influence reality". Writers, as creators, are free to invert what is commonly perceived as naturally feminine or masculine behavior. They can create their own reality. Though this is fantasy, it has the privilege of offering an alternative vision of society with different values, different definitions. Its power is in challenging the reader to think critically about the values of the society they inhabit outside of the fiction. To help the child reader to think outside of the assumptions about nature, gender and order they have been forced to embrace since birth and to start thinking for themselves. Children's Literature should challenge the reader, put our assumptions to the test, and question our reality. The danger of not challenging but simply reproducing stereotypes in Children's Literature is that writers risk creating a reality which is not there. The written word is a powerful tool and inspires a trust, an ultra-reality, because it is in a written form. It runs the danger of seeming more real, more desirable than the reader's life. Empirically, children are beginners and have not developed the capacity to criticize, to question crucially and effectually such an absolute authority as the written word.

If the ideas expressed in writing sanction behavior which excludes any deviation from socially defined gender ideals, readers who are unable to identify with this may feel freakish, different, marginalized. They may question where do they fit into this natural order, and, consequently, not fitting can cause a crisis of identity (Nebbia, 2016: pp. 16-23).

In William Golding's (1954/1987) Lord of the Flies ${ }^{7}$ we are introduced to a group of pre-adolescent boys who uprooted from the world of grown-ups are left to seek out a civilization of their own. The book is vivid, realistic and tragic. The theme is Hobbesian. We watch the rejection and overthrow of order, the embrace of superstition and tribalism as the boys try to make sense of their reality. Characters are marginalized, in the true Darwinian sense there is no room for the freak, the misfit. As Thomas Hobbes suggests, without "continuall feare" [sic], the life of a man becomes "solitary, poor, nasty, brutish, and short"

${ }^{7}$ It is notable here that Lord of the Flies was Golding's earliest novel, which first published in 1954 by Faber \& Faber, after many rejections the writer received from many other publishers. 
(Pogson Smith, 1965: p. 97). The couch which represents order is rejected, the resulting chaos is a provocative challenge to any ideas the reader might hold as to the essential goodness and innocence of children.

At the end of the book, Ralph weeps for "the end of innocence, the darkness of man's heart and the fall through the air of the true, wise friend called Piggy" (Golding, 1954/1987: p. 223). The treatment of Piggy in the novel, his marginalization from the group and his death are all related to his failure to embrace his socially defined gender characteristics. His name alienates him as sub-human. He is fat, immobile and be spectacled. He has asthma and bores the other boys with tales of his aunty and her sweetshop. He is feminized through his handicaps and his immobility. The society of the island will not tolerate him, this intolerance is manifested in his death. Utility is measured through the ability to hunt, through physical strength. Piggy's contribution is toward the preservation of reason and order. This is not valued he is ostracized, ridiculed and murdered.

Gender definitions do not simply stultify the natural expression of self, they encourage intolerance. Writers of children's fiction have the opportunity to subvert this intolerance by not parodying the individual but rejoicing in that individuality. Writers have a responsibility to encourage tolerance by not proposing unrealistic gender ideals in their fiction. With the sickening rise of fascism and intolerance in Europe currently, writers cannot afford to be dismissive of the very real influence their writing has upon their readers. Outside the arena of Children's Literature there are sufficient voices advocating intolerance without children's fiction writers, albeit unconsciously, joining the bandwagon.

Aidan Chambers (1982) in Dance on my Grave triumphs in challenging traditional gender definitions, while presenting the reader with a powerfully well written book. Heterosexuality is an essential part of gender definition, while homosexuality is viewed as at best unnatural, more commonly as depraved or disgusting. The homosexual is stereotyped in society, throughout the modern ages, as a freakish, mawkish creature, limp wristed, feminine and lisping. Although nowadays this stereotype is not the most commonly projected in the media, it still serves as a useful illustration of how gender through the accompanying evil of stereotyping is self-fulfilling. Chambers, by means of the characters of Hal and Barry, challenges the stereotyped homosexual. Both characters are masculine, intelligent, attractive and physical. The novel is surprising for the total absence of self-guilt in the characters or any attempt to justify or explain their sexual preference (e.g. in terms of sexual abuse, etc.). Their homosexuality is not an issue, it is a matter of fact (James, 2008; Trites, 2000).

What is crucial here is that the influence books have upon children is recognized. Writing which advocates stereotyped gender definitions as being the reality will influence and impress the children who read them. If those same children fail to fit the mould presented to them, they will be marginalized, feel deviant. They may try to repress, stultify their natural selves, striving to conform. It is individuality which is threatened. However successful individuals are in em- 
bracing their socially defined identities of masculinity and femininity their true natures must manifest somehow. This may not be a visible manifestation, swimming against natural current is hard work and cannot be sustained without damage. This is likely to be psychological and it will necessarily create inverted, covert, unhappy people. Lady Macbeth from Macbeth and Volumnia from William Shakespeare's Coriolanus, for example, are both striking examples of women striving against the crippling definitions of sexual identity. Powerless to act as women, they manifest their natures through the men closest to them. Both women appear monstrous and unfeminine. As women they are deprived of a public voice and must therefore use guile and manipulation to achieve their ends (Pollock, 2010; Aughterson \& Grant-Ferguson, 2020). Gender definitions, through dictating how men and women must behave, cause the frustration of true natures which must eventually find a vent. When this nature is manifested, it is often a corrupted, ugly thing, twisted and gnarled through repression. The failure of society to recognize the individual through its strive to rationalize existence is both dangerous and tragic.

\section{As an Epilogue}

Gender is not specific to Children's Literature, as its influence permeates all literature. The negative implications of stringent gender definitions are however more harmful and damaging to the child reader, since children in general are more impressionable than adults, while they are searching to find their identity, to establish their values, striving to be. The literature they read can either strengthen and empower their idea of self, or degrade that self. Innocence is both beautiful and infinitely corruptible. Thoughtless writing which either parodies individuals or creates ultra-realities of how we are to be through gender portrayal can shatter and degrade children's identities. If literature espouses unrealistic gender definitions as being normal, it will marginalize the individuals who don't fit in, it will create deviants. It is the individual who is threatened (Nebbia, 2016: pp. 16-23).

Some socially correct writing, on the one hand, while striving to positively portray marginalized areas of society, fails because it makes its intent too obvious. Education, on the other, is substituted for the story. The two do not need to be exclusive. The sacrifice of the fantastic, the imagination for social correctness is not feasible, and the price is too high (Nebbia, 2016: pp. 23-37). ${ }^{8}$

What we advocate is a Children's Literature which encourages children to question and to think. The limitations that gender definitions confer upon children, the problems gender stereotyping cause will not be resolved or combatted through literary texts as children's books are not the proper arena to host this debate, but they could be a starting point for critical reflection and revision of writing or reading styles. This is fodder for adults, it is we who should strive to

${ }^{8}$ For more insights on the various aspects relating to the gender-literary relationship see the individual studies in the special monographic issue: "Feminism and Gender in Literary Education" of Journal of Literary Education (No 3, 2020). https://ojs.uv.es/index.php/JLE/issue/view/1291. 
change the philosophies which dehumanize us, and through us to dehumanize individual children. Children's Literature should inspire its readers with confidence, confidence to be proud of their individuality, to rejoice in themselves. If literature is challenging, it will in turn teach the reader to challenge the dubious morality which confers normality upon unrealistic gender definitions, whilst defining anything other as unnatural, deviant, and emphasizing the "trans-sectional" and "transcultural" perspectives of gender (Jamison Green et al., 2019: pp. 44-45). Literature should never patronise self. In fact, as Karin Fry (2005: p. 156) states, "Children's books become interesting sites for gender studies, because they sometimes provide models for what girls and boys should be like in a given culture". Writers of children's fiction cannot be on their own subvert ideology which defines what we must be. They can however challenge children to think for themselves, to encourage their readers to discriminate between good and bad, to let them wonder!

Summing up, in Victoria Flanagan's (2010: p. 37) words,

"If we are to encourage children to see masculinity and femininity not as inherently binaristic and oppositional, but as relational and fluid, then writers, readers and critics need to be aware of how particular genres are gendered, of how narrative discourse can be used to privilege particular models of gender and how texts endorse or interrogate dominant cultural constructions of gender.”

\section{Conflicts of Interest}

The author declares no conflicts of interest regarding the publication of this paper.

\section{References}

Andersen, H. (1976). His Classic Fairy Tales (E. Haugaard, Trans.; M. Foreman, Illus.). Orion Publishing Co.

Aughterson, K., \& Grant-Ferguson, A. (Eds.). (2020). Shakespeare and Gender: Sex and Sexuality in Shakespeare's Drama. Bloomsbury. https://doi.org/10.5040/9781474290012

Butler, J. (2004). Undoing Gender. Routledge-Taylor \& Francis Group. https://doi.org/10.4324/9780203499627

Butler, J. (2006). Gender Trouble: Feminism and the Subversion of Identity. RoutledgeTaylor \& Francis Group.

Chambers, A. (1982). Dance on My Grave. The Bodley Head.

Copenhaver, B. B. (2002). A Portrayal of Gender and a Description of Gender Roles in Selected American Modern and Postmodern Plays. [Electronic Theses and Dissertations, Paper No. 632, East Tennessee State University]. http://dc.etsu.edu/etd/632

Dickens, C. (1987). Hard Times (D. Craig, Ed.). Penguin Books. (Original Work Published 1854).

Elwin, R., \& Paulse, M. (1990). Asha’s Mums (D. Lee, Illus.). The Women's Press.

Ernst, S. B. (1995). Gender Issues in Books for Children and Young Adults. In S. Lehr (Ed.), Battling Dragons: Issues and Controversy in Children's Literature (pp. 66-78). Heinemann. 
Ferrarelli, M. (2007). Children's Literature and Gender: A Critical Approach. Critical Literacy: Theories and Practices, 1, 63-68.

http://www.criticalliteracyjournal.org/cljournalissue1volume1.pdf

Flanagan, V. (2010). Gender Studies. In D. Rudd (Ed.), The Routledge Companion to Children's Literature (pp. 26-38). Routledge-Taylor \& Francis Group.

Fry, K. (2005). No Longer a Friend of Narnia: Gender in Narnia. In G. Bassham, J. L. Walls, \& W. Irwin (Eds.), The Chronicles of Narnia and Philosophy: The Lion, the Witch, and the Worldview (pp.155-166). Open Court Press.

Golding, W. (1987). Lord of the Flies. Faber and Faber. (Original Work Published 1954).

Goodman, L. (1996). Approaching Literature: Literature and Gender. Routledge-Taylor \& Francis Group.

Hamilton, V. P. (1990). The Book of Genesis: Chapters 1-17. Wm. B. Eerdmans Publishing Co.

Jabeen, I., \& Mehmood, A. (2014). Children Literature: Shaping Gender Identities. Asia Pacific Journal of Multidisciplinary Research, 2, 240-242.

James, K. (2008). Death, Gender, and Sexuality in Contemporary Adolescent Literature. Routledge-Taylor \& Francis Group. https://doi.org/10.4324/9780203885154

Jamison Green, J., Ashley Hoskin, R., Mayo, C., \& Miller, S. J. (2019). Navigating Trans and Complex Gender Identities. Bloomsbury Publishing.

Kramarae, C. (1981). Women and Men Speaking Frameworks for Analysis. Newbury House Publishers.

McCallum, R., \& Stephens, J. (2011). Ideology and Children's Books. In S. A. Wolf, K. Coats, P. A. Enciso, \& C. A. Jenkins (Eds.), Handbook of Research on Children's and Young Adult Literature (pp. 359-371). Routledge-Taylor \& Francis Group.

Nebbia, C. C. (2016). Gender Stereotypes in Children's Literature. Graduate Research Papers No. 680, University of Northern Iowa. https://scholarworks.uni.edu/grp/680

Opie, P. \& Opie, I. (Eds.). (1997). The Oxford Dictionary of Nursery Rhymes (2nd ed.). Oxford University Press.

Paul, L. (2004). Feminism Revisited. In P. Hunt (Ed.), International Companion Encyclopedia of Children's Literature (Vol. I, pp. 140-153). Routledge-Taylor \& Francis Group. https://doi.org/10.4324/9781315015729-10

Peterson, S. S., \& Swartz, L. (2008). Good Books Matter: How to Choose and Use Children's Literature to Help Students Grow as Readers. Pembroke Publishers Ltd.

Pogson Smith, W. G. (Ed.). (1965). Hobbes’s Leviathan. Clarendon Press. (Hobbes's Original Work First Published in 1651).

Pollock, J. (2010). “Not of a Woman's Tenderness To Be”: Shakespeare's Reassessment of the Notion of Femininity in Coriolanus. In: D. Lemonnier-Texier (Dir.), Représentations et Identités Sexuelles dans le Théâtre de Shakespeare: Mises en scène du genre, écritures de l'histoire (pp. 127-137). Presses Universitaires de Rennes.

https://books.openedition.org/pur/80907

Quinlan, P. (1987). My Dad Takes Care of Me (V. van Kampen, Illus.). Annick Press.

Swift, J. (2005). Gulliver's Travels (R. DeMaria Jr., Ed.). Oxford University Press. (Original Work Published 1726)

Temple, C. (1993). “What If ‘Beauty’ Had Been Ugly?” Reading against the Grain of Gender Bias in Children's Books. Language Arts, 70, 89-93.

Trites, R.S. (1997). Waking Sleeping Beauty: Feminist Voices in Children's Novels. University of Iowa Press. https://doi.org/10.2307/j.ctt20q1x3b 
Trites, R.S. (2000). Disturbing the Universe: Power and Repression in Adolescent Literature. Iowa University Press.

Wilkie-Stibbs, C. (2002). The Feminine Subject in Children's Literature. Routledge-Taylor $\&$ Francis Group.

Zipes, J. (2006). Why Fairy Tales Stick: The Evolution and Relevance of a Genre. Routledge-Taylor \& Francis. 